\title{
Adolesan Dönem Besin Seçimlerini Hangi Faktörler Etkiliyor?
}

\author{
Which Factors Affect Adolescent Food Preferences?
}

\begin{abstract}
Seray Kabaran, Seyit M. Mercanlıgil*

Doğu Akdeniz Üniversitesi, Sağlkk Bilimleri Fakültesi, Beslenme ve Diyetetik Bölümü, Gazimağusa, Kıbrıs

*Hacettepe Üniversitesi, Sağlık Bilimleri Fakültesi, Beslenme ve Diyetetik Bölümü,
\end{abstract} Ankara, Türkiye

Yazışma Adresi/Address for Correspondence Öğr. Gör. Seray Kabaran, Doğu Akdeniz Üniversitesi, Sağık Bilimleri Fakültesi, Beslenme ve Diyetetik Bölümü, Gazimağusa, Kıbrıs Tel.: + 3926303008 E-posta: seray.kabaran@emu.edu.tr Geliş Tarihi/Received: 14.01.2013 Kabul Tarihi/Accepted: 21.05.2013

(c) Güncel Pediatri Dergisi, Galenos Yayınevi tarafindan basilmıştir.

(c) The Journal of Current Pediatrics, published by Galenos Publishing.

\section{ÖZET}

Besin seçimlerini etkileyen çeşitli faktörler bulunmaktadır. Açlık, besinleri yemeye karşı duyulan istek, besinlerin lezzeti, besinlerin fiyatı ve uygun zaman besin seçimlerini etkileyen temel faktörler arasında yer almaktadır. Bunların yanında genel beslenme alışkanlıkları, aile, arkadaş çevresi, reklamlar ve besinlerin bulunabilirliği de besin seçimlerini önemli ölçüde etkilemektedir. Ayrıca, besinlerle ilgili geçmişten itibaren yaşanan deneyimler bazı besinlerin tercih edilmesi, bazı besinlerin ise tüketiminin reddedilmesi ile ilişkilendirilmektedir. Yaşın artışı ile sosyal ortamlarda bulunma sıklı̆ının artması sonucu adolesanların besin seçimlerinde değişiklikler ortaya cıkmaktadır. Günümüzde adolesanların "fast food" tarzı beslenme alışkanlıkları; arkadaşları ile dışarda zaman geçirmeleri; ayrıca besin endüstrisinin gelişimi ile hazır besinlerin, bisküvi, çikolata, cips ve kraker gibi atıştırmalıklıkların çeşidi ve tüketiminin artması ise sağlıksız beslenme alıșkanlıklarının ortaya çıkmasına neden olmaktadır. Tüm bunlar göz önünde bulundurularak, bu derlemede adolesanların besin seçimlerini etkileyen çevresel ve bireysel faktörler değerlendirilmiştir. (Güncel Pediatri 2013; 11: 121-7)

Anahtar kelimeler: Adolesan dönem, besin seçimleri, beslenme

\section{SUMMARY}

Hunger, extreme desire to eat a certain food, taste, price, and convenience are among the main There are various factors that affect food preferences. Hunger, extreme desire to eat a certain food, taste, price, and convenience are among the main factors affecting food preferences. Additionally, general nutritional habits, family, friends, commercials, and availability of the food are also important for food preferences. Also, past experiences with foods are related to preferring or rejecting some foods. Socializing more with increasing age causes change in the food preferences of adolescents. Unhealthy nutrition habits form as a result of the adolescents consuming fast foods, spending time with their friends outside the house, and consuming more ready-made foods. Current developments in the food industry result in an increase in variety and consumption of snacks such as cookies, chocolate, chips, and crackers in adolescents. Considering all these, in this rewiev article, environmental and personal factors affecting food preferences have been investigated. (Journal of Current Pediatrics 2013; 11: 121-7)

Key words: Adolescent, food preferences, nutrition

\section{Giriş}

Hangi besinlerin ve içeceklerin; nasıl, ne zaman, nerede ve kimlerle tüketileceği, besin seçimlerini ve yeme davranışlarını oluşturmaktadır. Besin seçimleri ise hangi besinlerin vücuda alınacağını belirleyerek sağlık durumunu etkilemektedir (1).

Adolesan dönemde besin seçimlerini ve yeme davranışlarını etkileyen çeşitli bireysel ve çevresel faktörler bulunmaktadır (Şekil 1). Bireysel özellikler arasında adolesanların genel davranışları, inançları, bilgi düzeyleri, kendi kendine yeterli olma durumları, vücut imajları ile besin ve lezzet tercihleri gibi psikososyal faktörler bulunmaktadır. Bunlara ek olarak açlık gibi biyolojik faktörler de yeme davranışlarını etkilemektedir. Ana ve ara öğün tüketim alışkanlığı, ağırlık kontrolü, zayıflama diyetlerinin uygulanması gibi davranışsal faktörler, ayrıca para, zaman sıkıntısı gibi yaşam şekli ile ilgili faktörler yeme davranışlarını etkilemektedir (1).

Adolesanların yeme davranışları ayrıca sosyal çevreden (aile, arkadaş) etkilenmektedir. Aile, arkadaş ve komşular ile ilişki düzeyi, yakın çevrede bulunan bireylerin örnek oluşturabilecek davranışları, medyanın etkisi, besinlerin fiyatları ayrıca sosyo-kültürel değerler ve yasalara göre ülkede beslenme ile ilgili uygulanan plan ve politikalar da besin seçimlerinde değişikliklere neden olmaktadır $(1,2)$.

Ülkede besinlerin üretimi ve bulunabilirliği kadar besinlere erişilebilirlik de besin seçimlerinde önemli etkiye sahiptir. Okul ortamı, okul kantinlerinde satılan besinler, çevrede bulunan restoranlar, alışveriş merkezleri ve hazır besinler adolesanların besin seçimlerine yön vermektedir (2). Besin 
seçimleri insanların çevresindeki birçok kompleks etkileşimin biraraya gelmesi ile oluşmaktadır (1). Adolesanların besin seçimleri ise yakın çevrelerinden ve birbirlerinden kolayca etkilenebilmektedirler (2). Bu derleme yazıda adolesan dönem besin tercihlerini etkileyen çevresel ve bireysel faktörler değerlendirilmiştir.

\section{Besin Seçimlerini Etkileyen Bireysel Faktörler}

\section{Açlık Durumu}

Açlıkfizyolojik bir dürtü olup besin alımında önemli etkiye sahiptir. Adolesan dönemde besin alımında değişikliklere neden olan faktörlerden biri de açlıktır. Adolesanların bir besini yemek istemesindeki nedenler arasında 'acıkmış olmak' veya 'o besini canı istemek' bulunmaktadır. Açlık özellikle atıştırmalık ara öğün seçimlerinde önemli bir faktör olarak yerini almaktadır (3).

\section{Cinsiyet}

Cinsiyet de adolesanların besin seçimlerini değiştirmektedir (1). Dört-14 yaş arası çocuk ve adolesanlarla yürütülen bir çalışmada kızların erkeklere göre meyve ve sebzeleri, erkeklerin ise kızlara göre yağlı ve şekerli besinleri, et ürünlerini, işlenmiş etleri ve yumurtayı daha fazla sevdiği belirlenmişstir (4). Erkeklerin enerji, toplam yağ ve doymuş yağ alımları kızlara göre daha yüksek olmaktadır. Kızlarda kahvaltı öğününü atlamanın da daha yaygın olduğu belirtilmektedir (1).

Zayıflamaya verilen önem adolesan kızlarda yaygındır. Medya etkisi ile adolesanlar kızların vücut imajına verdiği önem ve ağırlık kaybetme isteği artmaktadır Modanın takip edilmesi, manken ve modellerin zayıf olması ile kızların besin tercihleri etkilenmektedir. Dergilerin sık okunması dergilerde yayınlanan çok düşük enerjili diyetlerin uygulanmasına yol açmaktadır (5). Bu nedenle ilişkili

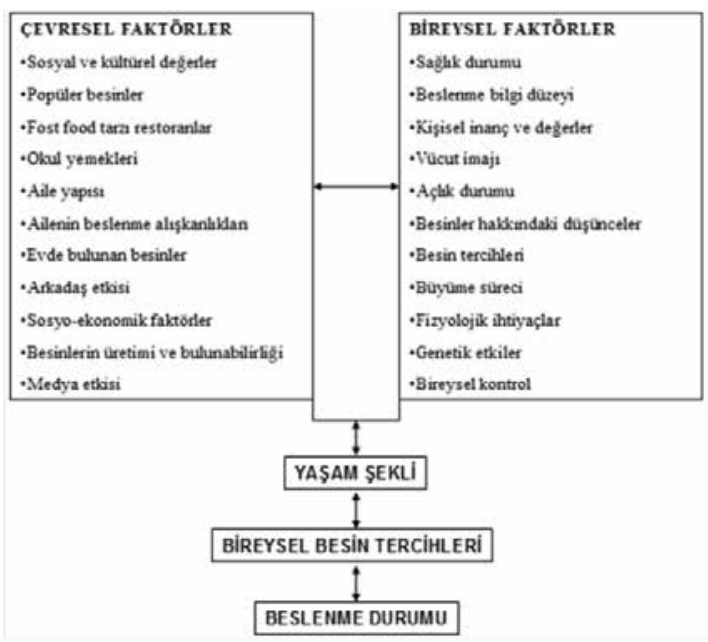

Şekil 1. Adolesanlarda besin tercihlerini ve yeme davranışlarını etkileyen çevresel ve bireysel faktörler $(1,2)$ olarak ağırlık kontrolü ile ilgili davranışlar ile besin alımları incelendiğinde; yağ içeriği yüksek besinlerin daha az, meyve ve sebzelerin ise daha fazla tüketildiği görülmektedir (3). Bu nedenle de vücut imajına önem veren adolesanların ağırlık kontrolünü sağlamak amacı ile yetersiz beslendikleri görülmektedir (5).

\section{Besinlerle IIIgili Yaşanan Deneyimler}

Yapılan çalışmalar besin seçimlerinin yaşamın erken döneminde oluşmaya başladığını ve çocukluk ve adolesan dönemi süresince benzer olarak devam ettiğini göstermektedir $(6,7)$. Bazı besinlerin tercih edilmesi, bazı besinlerin ise reddedilmesinin fetal dönemde amniyotik sıvıya geçen bazı besinlerin lezzetleri ve emziklilik döneminde anne sütüne geçen bazı besinlerin lezzetleri ile ilgili olduğu belirtilmektedir $(8,9)$.

Amniyotik sıvıdaki lezzet bileşikleri fetüsün; anne sütü içerisindeki lezzet bileşikleri anne sütü alan yenidoğanın; tamamlayıcı besinler ise yeni besinlerle tanışan bebeğin lezzet deneyimlerini oluşturmakta (10) ve çocukluk döneminde besinlerle ilgili yaşanan deneyimler ve tercihler de yaşamın ilerleyen dönemine kadar devam ederek besin seçimleri ve beslenme alışkanlıklarını oluşturmaktadır $(11,12)$. Yemek yeme gibi çocukluk çağındaki deneyimler, bu deneyimlere bağlı pozitif veya negatif sonuçlar, besinlere maruz kalma ve genetik nedenlerle (acı lezzetlere bağlı duyarlılık) biraraya gelerek besin seçimlerinin oluşmasında etkili olmaktadır $(3,7)$. Yapılan ileriye yönelik bir araştırmada da 2-3 yaştaki besin seçimlerinin adolesan dönemde de benzer olarak devam ettiği belirlenmiştir (6).

Son yıllarda yürütülen bir çalışmada da besinlerin lezzeti ile ilgili beklentinin besinlerle ilgili yaşanan önceki deneyimlerden etkilenebildiği, eğer bir besinin lezzeti beklenenden kötü olarak algılanmışsa sonrasında da bu besinin lezzetli olma beklentisinin azalabildiği saptanmıştır (13).

\section{Besinlerin Tat ve Lezzet Algısı}

Besinlerin tat ve lezzeti besin seçimlerini etkileyen temel faktörler arasında yer almaktadır $(14,15)$. Besinlerin lezzetine önem veren kişilerin düşük yağ içeren atıştırmalık besinlerle ilgilenmediği görülmüștür. Besinlerin görüntüsü de adolesanların besin seçimlerinde önem taşımaktadır (3).

Besinlerin lezzetine verilen cevaplarda genetik değişikliklerin de rolü olup genetik farkllıklar tüketilen besinlerin çeşidini ve miktarını değiştirmektedir (16). Tat reseptör genlerindeki değişiklikler çocuklarda özellikle acı ve tatlı lezzetlerin algılanmasındaki farkllıklar sonucunda besin seçiminde bireysel faklılıklara neden olmaktadır (17). Buna ek olarak ekşi lezzeti olan besinlerin seçiminde de genetik faktörlerin önemli katkısı olduğu saptanmıştır (18).

\section{Sağlıklı Beslenmeye Verilen Önem}

Sağlıkı beslenmenin önemi ve nedenlerinin farkında olmak, bu konuda bilgi sahibi olmak önemlidir. Fakat tek başına bilgi, sağlıkı beslenme alışkanlığı kazanmak için yeterli değildir. Adolesanların besin seçiminde, besinlerin 
besin değerinden çok lezzetlerinin ön planda olduğu belirtilmektedir (19).

Sağlıklı beslenmeyi olumsuz etkileyen yağ, şeker ve tuz tüketimi ile ilgili endişesi olan öğrencilerin bu bileşenleri içeren besinleri daha az sıklıkta tüketmeye çalıştıkları görülmektedir (20). Adolesanlarla yapılan bir çalışmada sağlıkla ilgili endişe duyanların besin seçimlerinin ayrıca sağlıklı yeme davranışlarının etkilendiği saptanmıştır (21).

Sağlıklı beslenmenin önemi, adolesanların besin tercihlerinde istenen etkiyi göstermemektedir. Yalnızca sağlıklı beslenmeye önem verenöğrencilerbesinlerin lezzeti, fiyatları veya açlık durumu dışında besinlerin düşük yağlı olmasına ve besleyici değerinin yüksek olmasına da önem vermektedir. Sağlıklı beslenmeye önem vermeyenlerin ise toplam yağ alımlarının yüksek olduğu vurgulanmaktadır (2). Adolesanlar hazır besinleri arkadaşları ile beraber olmak ve keyif almak için tükettiklerini belirtmekte, ayrıca hazır besinlerin ekonomik olduğunu düşünmektedirler. Bunların yanında hazır besinlerin ağırlık kazanımına neden olabileceğinin de fakında olduklarını belirtmektedirler. Sağlıklı beslenmeyi ise evde olmak, aile bireyleri ile sofrada oturmak ile ilişkilendirmektedirler (19).

Adolesanlar yeterli enerji alarak ağırıklarını, fiziksel görünümlerini korumayı ve okulda başarılı olmayı önemsemekte fakat bunların sağlıkı beslenme alışkanlıkları ile önemli ilişkisi olduğunu dikkate almamaktadırlar. Adolesanlar, sağlıklı beslenme alışkanlığı kazanmak ve düzenli beslenmenin, yetişkinlik dönemini ilgilendiren sorunlar arasında olduğunu düşünmektedirler $(1,3)$. Adolesanlar için şu anki sağllk durumları önemli olup, gelecekte yaşanabilecek sağlık sorunları endişe verici bir durum olarak algılanmamaktadır (1). Ne yazık ki adolesan dönemdeki farklı öncelikler sağlık ve beslenmeyi geri plana itmektedir (3). Adolesanlar, gelecekte karşılaşacakları sağlık sorunlarını önemsemeyerek yeme davranışlarını değiştirmek için çaba harcamamakta, besinlerden alınan kısa süreli tatmin, uzun süreli sağllk sorunlarına tercih edilmektedir (1). Yaşın ilerlemesiyle sağlıkı beslenmeye verilen önemin artacağı ve alışkanlıkların değişeceği belirtilmektedir (3).

\section{Zaman ve Uygunluk}

Zaman kısıtllığı da adolesanların besin secimleri ile doğrudan ilişkilidir $(1,3)$. Yeterli zamanın olmaması sağlıklı besinlerin tüketimi için temel engeldir. Adolesanlar aşırı yoğun olmaları nedeni ile sağıksız beslenme alışkanlıklarını sağlıkı olanlarla değisstirecekveya bu duruma endişelenecek zamanı bulamadıklarını belirtmektedirler $(22,23)$. Bu nedenle pratik ve hazır besinlere yönelmektedirler. Kahvaltı yapmak için hazır pastane ürünlerini, öğle yemekleri için atıştırmalık hızlı ve kolay hazırlanan hazır besinleri tercih etmektedirler (24).

Adolesanlar sağlıklı beslenmenin zaman alıcı olduğunu ve zahmetli bir seçenek olduğunu düşünmektedirler. Ayrıca sağlıklı beslenme konusunda kendi kendilerini kontrol etmenin zor olduğunu düşünmekte ve atıştırmalık hazır besinleri yemeye aşırı istek duymaları nedeni ile sağlıksız beslenme alışkanlıklarına yönelmektedirler (23).

\section{Besin Seçimlerini Etkileyen Çevresel ve Sosyal Faktörler}

Aile

Adolesanların yeme davranışlarını, besin tüketimlerini ve beslenme alışkanlıklarını etkileyen birçok çevresel faktör bulunmaktadır. Aile bireylerinin beslenme alışkanlıkları ise çocuk ve adolesanların beslenme alışkanlıkları, yeme davranışları ve besin seçimleri üzerinde temel etkiye sahiptir (25).

Aile sofrasında yemek yeme ve sofrada yenilen öğünlerin içerikleri, evde bulunan besinlerin çeşidi, evde hazır ve taze besinlerin bulunabilirliği, dışarda yemek yeme sıklığı, anne ve babanın besin tüketimleri ile anne ve babanın beslenmeye karşı tutum ve davranışları adolesanların beslenme alışkanlıklarını etkilemektedir (26). Ailelerin çocukları belirli besinleri yemeye zorlamaları, bazı besinlere karşı getirdikleri kısıtlamalar, örnek ve model olma durumları da çocuklarının beslenme alışkanlıkları ve vücut ağırlıklarını değiştirmektedir $(26,27)$. On bir-14 yaş çocuklarla yürütülen bir çalışmada da evde bulunan besinler, aile bireyleri tarafından tercih edilen besinler, besin hazırlama ile ilgili uygulamalar, finansal endişe veya sağllk endişesi gibi nedenler ile ailelerin çocukların besin seçimlerini etkiledikleri saptanmıştır (28).

Aileler besinleri sağlamanın yanında adolesanların besin tercihlerini etkilemekte ve yaşam boyu sürecek olan beslenme alışkanlıklarını kazanmalarını sağlamaktadır. Kazanılan alışkanlıklar ile adolesanların ileriki yıllarda bağımsız besin tercihleri oluşmaktadır. Aileleri ile beraber yaşayan adolesanlar aldıkları enerjinin ortalama \%65'ini evde yedikleri besinlerle karşılanmaktadırlar (3). Aile sofrasında yemek yeme ise adolesanların daha sağlıklı beslenmelerini sağlamaktadır (29). Özellikle yaşın artışı ile adolesanların aileleri ile beraber yemek yeme alışkanlıklarında değişiklikler oluşmakta, örneğin 12-14 yaş arası genç adolesanlar 15-17 yaş arası adolesanlara göre evde daha fazla yemek yemektediler (3). Yapılan bir çalışmada 12-14 yaş arası adolesanların \%74'ünün haftada 5 veya daha fazla kez aileleri ile beraber yemek yediği, 1516 yaş arası adolesanlarda bu oranın \%61'e, 17-19 yaş arası adolesanlarda ise \%42'ye düştüğü belirlenmiştir (19). Arkadaşlar ile zaman geçirme süresi artarken, sosyal aktiviteler nedeni ile akşam yemeklerini anne ve babaları ile beraber yeme sıklı̆ı azalmakta ve "fast food" tarzı hazır besinleri tüketme sıklığı artmaktadır. Bu nedenlerle sebze ve meyve tüketimi azalmakta, kızarmış besinlerin tüketimi ile alkolsüz içeceklerin tüketimi artmakta ayrıca doymuş yağ ve trans yağ alımı yükselmektedir (29). 
"Fast food" tarzı restoranlarda ekonomik mönüler adı altında büyük seçim veya ekstra seçenek sunulmakta, bu da adolesanların aşırı besin tüketmelerine neden olmaktadır. Hazır kolalı içecekler ve meyve suları yerine taze sıkılmış meyve sularının, kızarmış besinler yerine ızgara olanların ve büyük seçim mönüler yerine normal porsiyonların tercih edilmesi dışarıda tüketilen besinlerin sağlığı tehdit edici etkisinin azalmasına yardımcı olmaktadır (2).

Adolesanların aileleri ile en sık gerçekleştirdikleri ortak aktivite, akşam yemeğini beraber yemektir. Aile ve gençler arasındaki iletişim de adolesanların aileleri ile beraber yemek yemeleri ile ilişkilidir. Bu nedenle aile sofrasında beraber oturarak yemek yeme inmal edilmemelidir (30). Ailesi ile arasında sorun olan veya aile sofrasında servis edilen besinlerden hoşnut olmayan adolesanlar aileleri ile beraber yemek yememeyi tercih etmektedirler $(29,31)$. Düzenli bir yaşantısı olmayan, yoğun çalışan veya yemek saatlerinde çalışmak zorunda olan ailelerde düzenli olarak sofra kurulmamaktadır. Bu da adolesanların düzenli beslenme alışkanlığı kazanmalarını engellemektedir. Ayrıca yemek saatlerinde okul ile ilgili veya spor, müzik gibi sosyal aktivitelere katılmak zorunda olan adolesanlar veya arkadaşları ile sık sık dışarda zaman geçirmek isteyen adolesanlar da düzenli beslenme alışkanlığı kazanamamaktadır (3).

Aile ile akşam yemek yeme sıklığının artması ile sağlıkı beslenme alışkanlıkları kazanılmakta, meyve ve sebze tüketimi ve posa alımı artmakta, kızarmış besin tüketimi, doymuş yağ ve trans yağ alımı ve alkolsüz içecek tüketimi azalmaktadır (19). Aile ile beraber yemek yeme ile düzenli olarak kahvaltı, öğle yemeği ve akşam yemeği yeme sıklı̆ı artmaktadır. Düzenli olarak aile ile yemek yeme "fast food" tüketimi ile negatif ilişkilidir. Ayrıca düzenli olarak ailesi ile sofrada oturarak yemek yiyen ( $\geq 5$ öğün/hafta) adolesanların beslenme ile posa, kalsiyum, folat, demir, vitamin $B 6, B 12, C$ ve $E$ alımlarının daha yüksek olduğu belirlenmiştir (32).

\section{Demografik Ozellikler}

Aile yapısının değişmesi ile anne veya babasından ayrı yaşayan çocukların sayısı artmaktadır. Ayrıca çalışan anne sayısı da günümüzde yüksektir. Anne ve babanın çalışması veya tek ebeveyn olan aileler yemek hazırlamaya daha az zaman ayırmaktadırlar. Anne veya babası ile yaşayan çocukların ana öğün tüketmeyerek daha fazla atıştırmalık besin tükettikleri görülmektedir (32).

Yemek hazırlamak kadınların görevi olarak nitelendirilmektedir. 1900'lü yıllarda kadınların \%21'i çalışmakta ve kadınlar haftada 44 saatlerini yemek hazırlama ve temizlik için harcamaktaydı. 1950'li yıllarda kadınların \%29'u çalışmakta ve kadınlar haftada 20 saatten daha az zamanı yemek hazırlama ve temizlik işlerine ayırmaktaydı. 1998 ylında kadınların yaklaşık \%60'ı çalışmakta ve haftada 10 saatten daha az süreyi yemek hazırlama ve temizlik işlerine ayırmaktaydı. Çalışan kadınların oranının günümüzde daha da artması ve ev işlerine ayrılan sürenin azalması ile evde yemek yeme oranı da düşmektedir (19). "Fast food" tarzı besinlerin popülerliğinin, dışarıda yemek yeme sıkığının ayrıca hazır besinlere talebin artması evde pişirilen yemekleri yeme oranını azaltmıştır (5). Ailelerin sosyoekonomik durumu da besin alımı ve diyet kalitesini etkilemektedir (33). Gelir durumundaki yetersizlik, meyve tüketiminin azalması ile ilişkilendirilmektedir (19). Ayrıca adolesanlar besin tercihleri ile ailelerinin besin alışverişini de etkilemektedir. Atıştırmalıklar, tatılar, içecekler adolesanların besin alışverişinin temelinde yer almaktadır (34).

\section{Ücretler}

Besin tercihlerinde besinlerin tat ve lezzetinden sonra, açlık durumu, sonrasında ise fiyatları gelmektedir. Bu nedenle okullarda uygun fiyatlarda meyve, sebze ve düşük yağı atıştırmalık ara öğünlerin satılması sağlıkı beslenmeye yönlendirmektedir (1). Adolesanlar harçlıklarını "fast food" tarzı besinler ve atıştırmalık besinler için harcamaktadır (34). Taze sebze ve meyvelerin fiyatlarının \%50 azaltılmasının kantinlerde meyve ve sebze satışlarını 2-4 kat arttırdığı belirlenmiştir. Düşük yağlı ürünlerin fiyatlarının $\% 10, \% 25$ ve $\% 50$ düşürülmesi ise satışlarını sırasıyla $\% 9$, $\% 39$ ve \%93 oranında artırmıştır (35). Bu gibi sonuçlar fiyatların besin seçimi üzerindeki önemli etkisi olduğunu göstermekte, besleyici değeri yüksek olan besinlerin fiyatlarının yüksek olması da sağlıklı besin seçimlerini engelleyebilmektedir (36).

\section{Besinlerin Bulunabilirliği}

Ailelerin çocuklarının ev dışında tükettikleri besinleri kontrol edememeleri nedeni ile evde bulunan besinlere özen göstermeleri gerekmektedir (31). Ülkede besinlerin yetiştirilme durumu gibi besinlerin evde bulunması ve aile bireyleri tarafından tüketilmesi adolesanların besin seçimini etkilemektedir (35). Buzdolabında taze meyvelerin ön tarafta bulunması veya taze sebzelerin buzdolabının görünen taraflarında durması, adolesanları sağlıkı besinler seçmeye yönlendirmektedir (31). Evde meyve ve sebzelerin sık bulunması ve hazırlanması ile adolesanların meyve ve sebze tüketiminin yüksek olması arasında anlamlı ilişki bulunmaktadır (35).

\section{Yakın Arkadaş Çevresi}

Arkadaş etkisi adolesanlarda besin alımını etkileyen temel faktörler arasında yer almaktadır. Hazır ve atıştırmalık besin tüketimi arkadaşlar ile birlikte olma, eğlenme ile ilişkilendirilmektedir (37). Adolesanlar zamanlarının büyük kısmını arkadaşları ile geçirmektedirler. Yemek yeme de sosyal ortamların vazgeçilmez bir parçasıdır (38). Bu nedenlerle adolesanların besin seçimleri de, arkadaşları tarafından kabul edilme ve arkadaşlar ile beraber zaman geçirip eğlenme ile de değişmektedir (37). 
Adolesanlar ve ailelerinin besin seçimleri arasındaki ilişki ile adolesanlar ve arkadaş çevreleri arasındaki ilişki karşılaştıııldığında ailelerinin etkisinin daha yüksek olduğu belirlenmesine rağmen, ara öğünler ve atıştırmalık besin seçimlerinde arkadaş etkisi daha önemli bir faktör olarak göze çarpmaktadır. Arkadaşlar ile zaman geçirme, sosyal öğrenme, gözlemleme, taklit etme, örnek alma gibi davranışlar besin seçimlerindeki farklılıklarda önemli etkiye sahiptir. Grup içerisinde benzer besinlerin tercih edildiği ve adolesanların birbirlerini önemli derecede etkilediği görülmektedir. Bunlardan farklı olarak besinlerin tüketilen miktarları da birbirlerini etkilemekte örneğin aşırı kilolu adolesanların aşırı kilolu arkadaşları ile normal ağırıkta olan arkadaşları ile beraber yediklerine göre, daha fazla miktarda yemek yedikleri gözlemlenmiştir. (38).

\section{Okul Ortamı}

Okulda bulunan besinler, adolesanların besin seçimi üzerinde önemli etkiye sahiptir. Özellikle tam gün eğitim veren okullarda çocuklar zamanlarının büyük bir bölümünü okulda geçirmektedirler. Bu nedenle aldıkları enerjinin önemli bölümünü okulda karşılamaktadırlar (39).

Çocukluk ve adolesan dönemlerinde kazandırılan sağlıkı beslenme alışkanlıklarının pekiştirilmesinde okul ortamı büyük önem taşımaktadır. Okulda meyve, süt, meyveli süt gibi sağlıkı atıştırmalık besinlerin bulunması sağlıklı beslenme alışkanlıklarının kazandırımasında önemlidir. Ayrıca okulda öğle öğünlerinde besin çeşitliliği, porsiyon kontrolünün sağlanması da beslenme alışkanlıklarının şekillenmesinde önemli olmaktadır. Okullarda tüketilen alkolsüz içecekler, besin değeri düşük atıştırmalık besinler ise sağlıksız beslenme alışkanlıklarının ortaya çıkmasına neden olmaktadır (40). Adolesanlar yakın çevrelerinden ve birbirlerinden kolayca etkilenmektedirler. Bununla ilişkili olarak adolesanların alkolsüz içecekleri veya şekerlemeleri tüketmeleri, lezzetlerini beğeniyor olmaları ayrıca okullarda bu tür besinlerin bulunuyor olması ve arkadaşlarının da bu tarz besinleri tüketiyor olmasından kaynaklanmaktadır. Ayrıca bu tarz besinlerin reklamların etkisi ile adolesanlara sürekli olarak tanitılıyor olması da sık tüketilmelerine neden olmaktadır (2).

Okulda tüketilen öğle yemeğinin günlük enerji alımının \%35-40'ını karşıladığı belirlenmiştir. Öğrencilere yemekhane dışında öğle yemeği yeme şansı tanınması da sağlıksız besin seçimlerine neden olmaktadır. Kantinlerde hamburger gibi hazır ürünlerin hazırlanması ve satılması fast food tarzı besinlerin tüketimini artırmaktadır (3). Okullarda satılan besinlere müdahale edilmesi ile hem okulda hem de okul dışında tüketilen besinlerin çeşitlerinde değişiklikler ortaya çıktığı bu nedenle okullarda satılabilecek besinlerle ilgili politikalar yapılması ve uygulanması gerektiği vurgulanmaktadır (41).

Adolesanların sağlıklı beslenme alışkanlıkları kazanabilmeleri için okul kantinlerinde enerji, şeker ve yağ içeriği yüksek çikolata, gofret, cips, kolalı içecekler yerine ayran, taze meyve suyu, süt, meyve gibi besinlerin satışı ile tüketimlerine teşvik edilmelidir (40). Öğrencilerin öğle yemeklerini okul yemekhanelerinde, sağlıkı ve dengeli öğünlerle yemeleri sağlanmalıdır. Okul saatleri dışında okul dışındaki marketlerden veya restoranlardan besin satın alınmasının engellenmesi ile de adolesanların sağlıklı besinlere yönelmesi sağlanabilir. Ayrıca okullarda beslenme eğitimlerinin yapılması sağlıklı beslenme alışkanlıkları kazandırmak açısından önemli olup besin seçimleri öğrenme ile gelişebilmektedir (19).

\section{"Fast-Food" Tarzı Restoranlar}

"Fast food" tarzı restoranların sayısı her geçen gün artmaktadır. Bu tarz restoranları en çok tercih eden yaş gruplarından biri de adolesanlardır. Adolesanlar hızlı hazırlanan, lezzetli, ucuz besinleri tercih etmekte ve bunların tümü "fast food" tarzı besinlerin temel özellikleri arasında olmaktadır. "Fast food" tarzı restoranlarda çok sayıda mönü seçeneği sunulmakta ve seçme şansı verilmektedir. Ayrıca porsiyon miktarlarının fazla olması da adolesanlar tarafından tercihini artırmaktadır. Ek olarak "fast food" tarzı restoranlar resmi yerler olmayıp adolesanlara yönelik uygun sohbet ortamı sağlamakta ve kalabalık arkadaş grubu ile gitmeye uygun yerler oldukları için de tercih edilmektedirler (19). Ayrıca zamanın kısıtı olması durumunda "fast food" tarzı besinlerin servisinin hızlı olması ve dışarıda tüketilmelerinin mümkün olması nedenleri ile de tercih edilmektedirler (2).

Adolesanlar haftanın yaklaşık 2 günü "fast food" tarzı restoranlara gitmektedirler. On iki-17 yaş arası adolesanlar hafta sonları "fast food" tarzı restoranlarda yemek yemektedir. Özellikle 15-17 yaş arası adolesanlarda bağımsız yaşam hakim olup, "fast food" tarzı restoranlarda yemek yeme sıklığı da artmaktadır. "Fast food" tarzı restoranlarda yemek yiyen 12-19 yaş arası erkek adolesanların, aldıkları toplam enerjinin \%38,4'ünü yağdan ve \%13,8'ini doymuş yağdan sağladıkları görülmektedir (3).

"Fast food" tarzı restoranlarda yemek yeme alışkanlığından vazgeçemeyen adolesanlara beslenme eğitimleri verilerek kızarmış "fast food" besinler yerine ızgara olanların tercihi ile toplam yağ alımının azalması sağlanabilir. "Fast food" tarzı besinlerin yanında salata tüketme alışkanlığı geliştirilerek de doygunluk sağlanabilir ayrıca posa ve vitamin alımı artırılabilir. "Fast food" tarzı besinlerin yanında taze sıkılmış meyve suyu tüketimi ile vitamin C alımı arttıılabilir (42).

\section{Medya Etkisi}

Günümüzde adolesanlar medyanın etkin olduğu bir çevrede yaşam sürmektedir. Evler, okullar, arabalarda medya etkisi hakimdir. Televizyon kanalları, radyo kanalları, videolar, internet ortamı ve internet siteleri reklamlarla çeşitli ürünleri tanıtmaktadır (42). On-18 yaş adolesanların odalarında ayrı televizyon bulunması, 
kendi bilgisayarlarının olması ve internet kullanmaları reklamlar ile sık karşılaşmalarına neden olmaktadır. Küçük yaşlardan itibaren televizyon izlemeye başlama ve daha sonra televizyonun, yerini müzik dinleme, film izlemeye bırakması adolesanların sürekli olarak medya ile karşılaşmasına olanak sunmaktadır (3). Televizyon izlenmese bile sürekli açık olması, yemek saatlerinde televizyon karşısında yemek yeme, besin seçimlerini etkilemektedir (43). Reklamları yapılan ürünler arasında kolalı içecekler, hamburger veya benzeri "fast food" tarzı besinler hazırlayan restoranlar, atıştırmalık çikolata ve cipsler, şekerlemeler, tatlandırımış kahvaltılık tahıllar, tuzlu krakerler bulunmaktadır. Meyve ve sebzelerin reklamları ise yetersiz olmakta veya dikkat çekici olmamaktadır (42). Son yıllarda yapılan bir çalışmada aileler sağlıklı besinlere yönlendirseler dahi çocukların reklamlarla tanıtılan besinlerden (sağlıklı veya sağlıksız) önemli ölçüde etkilendiği belirlenmiştir. Bu nedenle sağlıklı besinlere yönlendiren reklamların yapılması çocukların besinlerin seçimlerini olumlu yönde etkileyebilir (44).

Televizyon izleme süresi ile çocuk ve adolesanlarda obezite arasında anlamlı ilişki bulunmaktadır (45). Televizyon izleme süresinin artması fiziksel aktivitenin azalması ile enerji harcamasının azalması gibi, televizyon karşısında besin tüketilmesi ile toplam enerji alımı artmaktadır (46). Adolesanlarda televizyon karşısında geçen süre ile obezite arasında ilişki bulunmaktadır. Televizyon izleme süresindeki 1 saatlik artışın obezite prevalansını \%2-6 artırdığı belirtilmektedir. Televizyon izleme ile alınan günlük enerji 167 kkal artmaktadır. Televizyon izleme süresi ile atıştırmalık ara öğün tüketme sıklığı da yükselmektedir. Besin değeri düşük olan besinler tercih edilmekte ve meyve, sebze tüketimi ayrıca süt içimi azalmaktadır. Televizyon karşısında pizza, hamburger, cips, bisküvi, kolalı içecekler, meyve suları tüketilmektedir (45).

Ayrıca televizyon izleyerek adolesanlar reklamlarda yeni ürünler ile tanışmakta ve bu ürünlerin merak edilerek tüketilmesi ile enerji alımı daha fazla artmaktadır (46). Şeker, yağ ve tuz içeriği yüksek besinlerle sürekli karşılaşma ve deneme, sağlıklı besinlerden uzaklaşmaya neden olmaktadır $(46,47)$. Özellikle aşırı kilolu ve obez çocuklarda televizyon izleme ile karbonhidrat ve yağ içeriği yüksek besinlerin tercihinin artığı görülmektedir (47). Televizyonda eğlenceli bir besinin reklamının yapılması denenme isteğine neden olmaktadır. Televizyon aracilığı ile tanışılan besinin tadının denenmesi ile beğenilirliği artmaktadır. Televizyon programları arasında reklamlar ile verilen mesajlar; lezzetlerinin güzel olması, mutluluk vermesi, eğlendirici olması, havalı olmayı sağlaması gibi mesajlardır (46). Anneler de televizyonlarda yapılan reklamların çocukları sağlıksız seçeneklere yönlendirdiğini düşünmektedirler (48).

\section{Sonuç ve Öneriler}

Adolesan dönemde yeme davranışlarını, besin seçimlerini ve beslenme alışkanlıklarını etkileyen birçok çevresel faktör bulunmaktadır. Ailenin beslenme alışkanlıklarının çocukların beslenme alışkanlıkları ve besin seçimleri üzerinde önemli etkisi bulunmaktadır. Günümüzde çocukların "fast food" tarzı beslenme alışkanlıklarına sahip olmaları, arkadaşları ile dışarıda zaman geçirmeleri ve besin endüstrisinin gelişmesi sonucunda hazır besinler, bisküvi, çikolata, cips, krakerler gibi atıştırmalıkların çeşitlerinin ve tüketiminin artması ile çocuklarda özellikle sebze ve meyve tüketiminin yetersiz kaldığı, böylece vitamin mineral alımlarının düşük, toplam yağ, doymuş yağ alımlarının yüksek olduğu görülmektedir. Yetersiz ve dengesiz beslenmenin engellenmesi için çocukların öncelikle aile içinde sağlıklı besin seçimlerini öğrenmeleri gereklidir.

Beslenme eğitimleri ile öncelikle ailelerin eğitilmesi ve çocukların da okullarda verilecek eğitimlerle bilinçlendirilmesi, sağlıklı beslenme alışkanlıklarının kazandırımasında etkili olabilir. Okullarda beslenme eğitimi derslerinin sürekli hale getirilmesi ya da beslenme ile ilgili seminerlerle kursların verilmesi ile yeterli ve dengeli beslenmenin sağlıkla ilgili önemi vurgulanabilir.

\section{Kaynaklar}

1. Neumark-Sztainer D, Story M, Perry C, Casey MA. Factors influencing food choices of adolescents: findings from focus-group discussions with adolescents. J Am Diet Assoc 1999;99:929-37.

2. Gorin AA, Crane MM. The obesogenic environment, Jelalian E, Steele RG. (eds.) Handbook of Childhood and Adolescent Obesity. Springer Science, Business Media LLC. New York, USA 2008:145-61.

3. Story M, Stang J. Understanding adolescent eating behaviors, Stang J, Story M. (eds.) Guidelines for Adolescent Nutrition Services. Center for Leadership, Education, and Training in Maternal and Child Nutrition, Division of Epidemiology and Community Health, School of Public Health, University of Minnesota, Minneapolis 2005:9-20.

4. Cooke LJ, Wardle J. Age and gender differences in children's food preferences. Br J Nutr 2005;93:741-6.

5. Story $M$, Neumark-Sztainer D, French S. Individual and environmental influences on adolescent eating behaviors. J Am Diet Assoc 2002;102:40-51.

6. Nicklaus S, Boggio V, Chabanet C, Issanchou S. A prospective study of food preferences in childhood. Food Qual Prefer 2004; 15:805-18.

7. Nicklaus S, Boggio V, Chabanet C, Issanchou S. A prospective study of food variety seeking in childhood, adolescence and early adult life. Appetite 2005;44:289-97.

8. Beauchamp GK, Mennella JA. Flavor perception in human infants: development and functional significance. Digestion 2011;83:1-6. 
9. Mennella JA, Jagnow CP, Beauchamp GK. Prenatal and postnatal flavor learning by human infants. Pediatrics 2001;107:E88.

10. Beauchamp GK, Mennella JA. Early flavor learning and its impact on later feeding behavior. J Pediatr Gastroenterol Nutr 2009;48:25-30.

11. Mennella JA, Beauchamp GK. Understanding the origin of flavor preferences. Chem Senses 2005;30 Suppl 1:i242-3.

12. Skinner JD, Carruth BR, Bounds W, Ziegler P, Reidy K. Do food-related experiences in the first 2 years of life predict dietary variety in school-aged children? J Nutr Educ Behav 2002;34:310-5.

13. Robinson E, Blissett J, Higgs S. The influence of recent tasting experience on expected liking for foods. Food Qual Prefer 2013;27:101-6.

14. Drewnowski A. Warren-Mears V. Role of taste and appetite in body weight regulation, Coulston AM, Rock CL, Monsen ER. (eds.) Nutrition in the Prevention and Treatment of Disease. Academic Press, San Diego, USA 2001:539-45.

15. Drewnowski A. Taste Preferences and food intake. Annu Rev Nutr 1997;17:237-53.

16. Galvão $A C$, Krüger RC, Campagnolo $P D$, Mattevi VS, Vitolo MR, Almeida S. Association of MAOA and COMT gene polymorphisms with palatable food intake in children. J Nutr Biochem 2012;23:272-7.

17. Mennella JA, Pepino MY, Reed DR. Genetic and environmental determinants of bitter perception and sweet preferences. Pediatrics 2005;115:216-22.

18. Törnwall 0, Silventoinen $\mathrm{K}$, Keskitalo-Vuokko K, Perola M, Kaprio J, Tuorila H. Genetic contribution to sour taste preference. Appetite 2012;58:687-94.

19. Moreno LA, Rodriguez G, Fleta J, Bueno-Lozano M, Lazaro A, Bueno G. Trends of dietary habits in adolescents. Crit Rev Food Sci Nutr 2010;50:106-12.

20. Power TG, Bindler RC, Goetz S, Daratha KB. Obesity prevention in early adolescence: student, parent, and teacher views. J Sch Health 2010;80:13-9.

21. Sun YH. Health concern, food choice motives, and attitudes toward healthy eating: the mediating role of food choice motives. Appetite 2008;51:42-9.

22. Croll JK, Neumark-Sztainer D, Story M. Healthy eating: what does it mean to adolescents? J Nutr Educ 2001;33:193-8.

23. Nowak M, Büttner P. Relationship between adolescents' food-related beliefs and food intake behaviors. Nutr Res 2003;23:45-55.

24. Deshmukh-Taskar PR, Nicklas TA, O'Neil CE, Keast DR, Radcliffe JD, Cho S. The relationship of breakfast skipping and type of breakfast consumption with nutrient intake and weight status in children and adolescents: The National Health and Nutrition Examination Survey 1999-2006. J Am Diet Assoc 2010;110:869-78.

25. Favora A, Santonastaso P. Effects of parents' psychological charactesristics and eating behaviour on childhood obesity and dietary compliance. J Psychosom Res 1995;39:145-51.

26. Shrewsbury VA, King LA, Hattersley LA, Howlett SA, Hardy LL, Baur LA. Adolescent-parent interactions and communication preferences regarding body weight and weight management: a qualitative study. Int J Behav Nutr Phys Act 2010;7:16.

27. Matheson DM, Robinson TN, Varady A, Killen JD. Do MexicanAmerican mothers' food-related parenting practices influence their children's weight and dietary intake? J Am Diet Assoc 2006;106:1861-5.
28. Holsten JE, Deatrick JA, Kumanyika S, Pinto-Martin J, Compher CW. Children's food choice process in the home environment. A qualitative descriptive study. Appetite 2012;58:64-73.

29. Gillman MW, Rifas-Shiman SL, Frazier AL, Rockett HR, Camargo $\mathrm{CA}$ Jr, Field AE, et al. Family dinner and diet quality among older children and adolescents. Arch Fam Med 2000;9:235-40.

30. Koletzko B, Toschke AM. Meal patterns and frequencies: do they affect body weight in children and adolescents? Crit Rev Food Sci Nutr 2012;50:100-5.

31. Olsen S0, Ruiz S. Adolescents' influence in family meal decisions. Appetite 2008;51:646-53.

32. Burgess-Champoux TL, Larson N, Neumark-Sztainer D, Hannan PJ, Story M. Are family meal patterns associated with overall diet quality during the transition from early to middle adolescence? J Nutr Educ Behav 2009;41:79-86.

33. Han JC, Lawlor DA, Kimm SY. Childhood obesity. Lancet 2010;375:1737-48.

34. Collison KS, Zaidi MZ, Subhani SN, Al-Rubeaan K, Shoukri M, AlHohanna FA. Sugar-sweetened carbonated beverage consumption correlates with BMI, waist circumference, and poor dietary choices in school children. BMC Public Health 2010;10:234.

35. Di Noia J, Contento IR. Fruit and vegetable availability enables adolescent consumption that exceeds national average. Nutr Res 2010;30:396-402.

36. Monsivais P, Mclain J, Drewnowski A. The rising disparity in the price of healthful foods: 2004-2008. Food Policy 2010;35:514-20.

37. Moreno LA, Rodriguez G, Fleta J, Bueno-Lozano M, Lazaro A, Bueno G. Trends of dietary habits in adolescents. Crit Rev Food Sci Nutr 2010;50:106-12.

38. Wouters EJ, Larsen JK, Kremers SP, Dagnelie PC, Geenen R. Peer influence on snacking behavior in adolescence. Appetite 2010;55:11-7.

39. Ells LJ, Campbell K, Lidstone J, Kelly S, Lang R, Summerbell C. Prevention of childhood obesity. Best Pract Res Clin Endocrinol Metab 2005;19:441-54.

40. Wouters EJ, Larsen JK, Kremers SP, Dagnelie PC, Geenen R. Peer influence on snacking behavior in adolescence. Appetite 2010;55:11-7.

41. Wordell D, Daratha K, Mandal B, Bindler R, Butkus SN. Changes in a middle school food environment affect food behavior and food choices. J Acad Nutr Diet 2012;112:137-41.

42. Spear BA. Adolescent growth and development. J Am Diet Assoc 2002;102:23-9.

43. Reilly JJ. Physical activity, sedentary behaviour and energy balance in the preschool child: opportunities for early obesity prevention. Proc Nutr Soc 2008;67:317-25.

44. Ferguson CJ, Munoz ME, Medrano MR. Advertising influences on young children's food choices and parental influence. J Pediatr 2012;160:452-5.

45. Dennison BA, Edmunds LS. The role of television in childhood obesity. Prog Pediatr Cardiol 2008;25:191-97.

46. Harris JL, Bargh JA. The relationship between television viewing and unhealthy eating: Implications for children and media interventions. Health Commun 2009;24:660-73.

47. Boyland EJ, Halford JC. Television advertising and branding: Effects on eating behaviour and food preferences in children. Appetite 2013;62:236-41.

48. Yu JH. Mothers' perceptions of the negative impact on TV food ads on children's food choices. Appetite 2012;59:372-6. 